\title{
FRAMING WOMEN POLITICIAN IN DEMOCRATIC ENVIRONMENT: A STUDY OF MEGAWATI SOEKARNO PUTRI AND HILLARY CLINTON
}

\author{
Nurlita Hapsari \\ lita.lohita@yahoo.com
}

\begin{abstract}
This research was aimed to examine how media coverage produces particular framing toward women politician during presidential campaign as well as the significance behind the framings toward gender conception in Indonesia and America. Media holds a vital political role as it helps shaping people's opinion over particular issues and figures. As media coverage toward particular candidates can profoundly affect election outcomes, it is interesting to see how media presents two women figures who ran for presidential race.

This is a qualitative research. The main sources of data are articles gathered from eight online-based mainstream news sources from Indonesia and America. The secondary data are all selected works or research related to the topic such as reference books and journals.

This research was done under the framework of American Studies. Since American Studies is interdisciplinary, it involves various theories and disciplines. This research uses gender theory to observe how media shapes the image of women politician through their news coverage. Critical discourse analysis is used to explore the significance of media framing on women politician to society's conception of women's gender roles. Then, framing theory is important to analyze media's method and ideology in constructing the facts within the coverage.

In the research analysis, it is found that there are various framings used by media to describe Hillary Clinton's and Megawati Soekarno Putri's personalities. While media in both countries put on different focuses, news coverage on both media shares the same women stereotyping theme such as emphasis on physical appearance and family association. In the end, learning from the media framing toward woman politician, we can conclude that despite feminist achievement in many areas, woman are still highly perceived as unfit to be in political world.
\end{abstract}

Keywords: gender, politics, media, framing

\section{Introduction}

Democracy becomes essential in understanding America as a whole nation because it symbolizes not merely a political system, but rather an entire civilization (Singh, Skidmore, and
Sequiera, 1995) that has been shaping the characters of America itself. Being the father of modern democracy, America has come a long way to 'promote' democratic ideology to the world. However, we should note that there are always two faces 
of America; the ideal and the real. There are times when the ideal is disrupted by the fact that what happens in the actual field is much different from the initial plan. Due to various reasons, the implementation of democracy does not guarantee to favor the common good. Historically speaking, the Constitution itself was actually the product of a small group of elites who acted and formulated the Constitution for their own sake. Owing to this nature, American democracy is prominently influenced by particular groups in power with their own interests, such that make it inadequate to represent all voices of Americans (ibid). While democracy is supposed to guarantee equal rights for all citizens in terms of political involvement, uneven number of officer and power holder in the Senate and Congress implies how white and male politicians still hold the highest privilege in American democracy.

Despite contemporary number of women holding the highest political functions abroad such as German Chancellor Angela Merkel, United Kingdom Prime Minister Theresa May, and Bangladesh Prime Minister Sheikh Hasina, somehow politics is still widely regarded as male business in the United States of America. Many people argue that politics deals with "manly men, doing manly things, in manly ways," (DuerstLahti in Holtz-Bacha, 2013). Owing to this prevalent conception in the society, no wonder that until 2017, compared to other 'younger' democratic countries, America has yet to witness a woman rise to the presidency. Regarding to complexity of society's perception towards woman as leader, it is inevitable that their presidential candidacy always comes with controversy. Among the most astonishing and contentious elections in American political history is the 2008 Presidential Election, where Democrat party ran two candidates for President Nominee which both come from minority groups: a woman and a male African-American. However, we should note that they were running for a position where the default type is a white man. It would not be as easy as falling off a log to change society's perception about a female or Black president. As a consequence, both candidates had to run not only against each other but also against rigid construction in the public expectation of what a president is (Caroll, 2009).

In Democrat's 2008 presidential candidacy, Barrack Obama won over Hillary Clinton. Many scholars argue, especially the feminist ones, that there was a gender bias in media coverage of these 
two candidates during presidential candidacy. If some said that America is not ready to have their first woman president (which explains why Obama, a male African-American, is preferred), this notion is not necessarily true. According to the study, 55\% Americans are ready to have a woman president (Harper, "Gender bias did in Clinton?”). Then the question remains; why is there no woman in the White House as yet?

The possible answer for woman's inability to shatter the ceiling glass in White House might be owing to the existence of gender bias in the media coverage. Women consistently got less coverage than male candidates in the same race, and this did not improve over time. Sexism, more than ideology, has driven media's anti-Clinton theme that the press used many tricks to swipe at Clinton (Bedard, "Media Sexism Doomed Hillary’s 2008 Bid”). Hillary’s defeat from Barrack showed us that when gender is encountered with race, race seems to gain more privilege in the society. One possible reason for this phenomenon can be traced back from the nation's historical pattern.

"Black men were given the vote a half-century before women of any race were allowed to mark a ballot, and generally have ascended to positions of power, from the military to the boardroom, before any women," (Steinem, "Women Are Never FrontRunners").

That being said, when people have to choose between men vs. women within a bigger scope of gender vs. race, it seems that the answer remains on the favor of man, despite the fact that he comes from minority group. Thus, applying this hypothesis in 2008 Presidential Election, there was no room for a woman to be a president simply because U.S president should be a man, even if it means a Black man.

On the other side of the globe, as a newly-born democratic country, Indonesia was earlier than America to have its first female president. Taking the throne from former president Abdurrahman Wahid in 2001 to 2004, Megawati Soekarno Putri was the first female president in Indonesian political history. DPR's (People's Consultative Assembly) announcement to raise Megawati as president is quite interesting, given that Indonesia has the biggest Muslim community in the world. The influence of Islamic teachings is profoundly-spread in every aspect of Indonesian's society, including in politics. Some Islamic leaders have strict teaching that only men can be a leader (khalifah), while women should just 
be a loyal and obedient follower. Based on this view, women stand no chance to be a group leader, let alone to be the president of the nation.

In 2004, when her presidential duties ended, Megawati ran for the presidential election for the second time. This time, Megawati's party had to deal with not only her political opponents, but also attacks from the right wing. The largest religious organization in Indonesia, MUI (Board of Islamic Leaders) issued a fatwa (religious instructions) stating that it is forbidden for a woman to be a primary leader, such as president and governor (Liputan6, "MUI Yogyakarta Mengeluarkan Fatwa Haram soal Capres”). While the fatwa did not necessarily refer to Megawati, it affected her candidacy and might break her step to the throne. The issue of whether or not a woman can be a leader has always been becoming a polemic that leads to continuous debate among MUI bigwigs. However, considering how the fatwa was raised during the very moment of presidential election, there was an implication that the fatwa was occupied with political interest rather than public's interest.

By comparing what happened to Hillary and Megawati, we can see that both women had to face great obstacles in their way to presidency. Despite the existence of democratic ideology which offers equality, it seems that traditional and cultural gender view remains critical in how society perceives woman as a leader in both countries. As many have noted, traditional value in almost every society always puts women in the lower position than men. According to this value, a woman is not suitable to be a leader because naturally, her main duty is giving birth and nurturing children. So when a woman tries to break this traditional value, that is becoming a leader, she will be considered as evil, witch, or even monster for being too 'greedy' for power that she should not own. Women are excluded from many kind of jobs because the men who control the jobs define them as 'stupid', ‘delicate', and 'emotional,' (Zanden, 1988). Here, women are distinguished for their emotional feelings. While in the workplace, as men argue, rational thinking is more important than emotional feelings. Therefore, it further confirms the conception that women should just stay at home and take care of the children to justify women's exclusion from job opportunity, such as those in political area.

Politics is still widely conceived as men's territory, so is the default type of a 
president. Consequently, when a woman runs for presidential candidacy, she has to work more than their fellow men in order to get acknowledged by the constituents. Nowadays, the advance of technology has made it easier to do that. With the help of media power, each candidate builds their own image to appeal the voters. Media remains to be an effective means to promote and spread information because it can reach wide mass and audience. Thus, media creates such kind of imagery and frames toward certain political figure either to support or bring them down.

Women's position in political arena has always been inferior to men. So is their position in media. A research found that it is common for women to get less news coverage than men during campaign (Holtz-Bacha, 2013). Much worse, when they manage to get news coverage, media tends to deliver negative traits and usually focuses on their private life such as family, hobby, and physical appearance, rather than their achievement in leadership and political activities. This kind of coverage, more or less, does contribute in their winning or losing in the elections because society's perception is greatly influenced by media.

Thus, in this research, I analyze how media has shaped and framed Hillary
Clinton in her 2008 presidential candidacy and Megawati Soekarno Putri in her 2004 presidential campaign. Megawati and Hillary represent two of the most prominent women politician in their countries. However, it should be noted that they are not 'ordinary women' because they were wife and daughter of former leaders in America and Indonesia. With 'great' men behind their backs, it comes as no surprise that these male figures leave significant influences in these women's way to presidency.

\section{Methodology}

This research is conducted under the framework of American Studies. American Studies in itself belongs to interdisciplinary field, which is beneficial to obtain not only a new angle on traditional subject matter, but also to look on an event from several angles. Additionally, the concept of culture in American Studies revolves, cuts across, and includes the content of all other disciplines (Sykes, 1963: 254-256). Since the research discusses about women politician, women studies on gender theory is used to see traditional and cultural views on women gender role.

Gender, that is the feminine and masculine, is not born into one, but rather 
emerges as one develops and experiences life. It is a socially-constructed concept created through various network of forces that intersects as one grows. More or less, gender concept affects our way of seeing and understanding things. For example, gender role has been successfully excluding women's access from leadership and decision-making positions either in domestic or public area (Lois, 2006).

Socio-historical approach is also important to see the past and present of political life in America and Indonesia in order to understand why particular political issue arising in both countries. Furthermore, communication theory such as media framing is used because the research deals with how media represents women.

McDowell's concept of past, present, and future in American Studies is also important in this research. "Today American Studies are using the resources of the new learning to bridge past and future,” (McDowell, 1984). It means that by looking at the past and learning about it, we might understand the reasons of why something happens in the present. By evaluating the past, we find explanations about present conditions, and thus predict what will happen in the future.
This research also applied McDowell's reconciliation of region, nation, and world concept. Looking geographically, it is no doubt that Indonesia is far away from the United States. However, historically, Indonesia and America have been interrelated since a long time ago even before Indonesia is independent from Dutch colonialism. In a book entitled American Visions of the Netherlands East Indies/Indonesia: US Foreign Policy and Indonesian Nationalism 1920-1949 (2003), Francis Gouda explains how American democracy has influenced Indonesian later independence.

By comparing two women politicians running for presidential candidacy in two democratic countries, the study would like to find out how democracy has been adopted in politics and gender both in the United States and Indonesia.

The main data of the research are collections of curated news coverage related to Hillary Clinton's and Megawati Soekarno Putri's presidential candidacy. For Hillary, the news are taken from five most popular websites based on Nieman Lab’s Top 15 newspaper sites of 2008 as follows; The New York Times, USA Today, The Washington Post, The Los Angeles 
Times, and The Wall Street Journal. While for Megawati, the news from three most popular websites based on Alexa Rank; Detik, Liputan6, and Tempo are used. The popularity of these particular media at the time (2004 and 2008) becomes the main consideration of choosing the data. More popular the news platform means more people read and follow them, which also means that it will shape more people's opinion. Although Kompas and Tribun news are noted on Alexa Rank with high scores, they are not included in the research because there are no published article archives from 2004.

Despite the utmost efforts done to find the same amount of articles from Indonesia and America, it is inevitable that the data cannot be apple-to-apple. Owing to the lack source of data, the number of articles analyzed in this research is not the same (25 articles on Hillary and 14 articles on Megawati).

In analyzing the data, this research uses Critical Discourse Analysis (CDA), especially Teun van Dijk's theory. CDA is used to see how a text is established by observing the social and political context in which the text is shaped and developed. This theory is developed from the idea that there is no such thing as 'value-free' (van Dijk, 2001), because a text does not merely fall from the sky or emerge from a vacuum, but rather formed by a particular discourse in the society. This discourse is closely related to power control which dominates and even hegemonizes certain groups. For example, when a text is written with strong sense of women marginalization, it requires an observation of how the text can work and take form.

Van Dijk combines three dimensions of discourse analysis; text, social cognition, and context (Eriyanto, 2001). In text dimension, van Dijk observes basic components of a text, such as the theme, the framework, as well as the writing style and word choice. Then, social cognition refers to the awareness, knowledge, or point of view which is used by journalist or writer in the process of text production.

Within CDA, theory of media framing analysis is used to scrutinize the data (news texts). Framing analysis is an approach to see the journalist' perspective in selecting an issue and writing the news to be more meaningful and appealing to the readers (Sobur, 2001). However, the salience of news should be in accordance with the society's belief and ideology so it can be accepted by the society. Thus, the use of categories and stereotypes become an important element in framing theory (ibid). The involvement of journalist' 
perspective, value, and ideology play an important role in deciding which facts to deliver, to emphasize, or to ignore. According to Robert Entman, there are four functions of framing, including problem identification (seeing an event as positive or negative), causal interpretation (seeing the source of problem), moral evaluation, and treatment recommendation (Entman in Sobur, 2001).

\section{Discussion}

Thanks to the advancement of technology, everything can be found easily on the internet today. 'If you cannot find something on the internet, maybe that thing actually never exists in the real world too'. This expression shows the prevalent influence of internet in nowadays lifestyle. With the advance of technology and information, latest news are discovered and created in seconds. To accommodate people's need for quick and reliable news source, many once printedbased newspapers are now moving their platform to online-based news website. Despite the change of media, the news principle remains the same. In presenting particular news, topics, or issues, journalists are greatly influenced by their point of view to develop certain opinion towards the matters. Because of this viewpoint, media will select particular issues that fit their norms and values to construct the outline of their news. And thus, framing is the outcome of this process.

In this research, it is found that there are five most common themes used by media in their framing of women politician.

\section{Family and Personal Issue}

It is irrefutable that women and family is an inseparable entity. Based on this notion, the belief that the best place for every woman is in their home and the only career they can pursue is housewife has always been rooted and ingrained in the society. Supported by values and norms which favor patriarchal system such as religion, the notion that women should just stay at home becomes the basic reason to prevent women from working outside the home, including in politics. That being said, it is no surprise that media keeps showing a bias tendency when it comes to the representation of woman politician. In the coverage of female politicians, media often put on wrong focus and attention by talking more about trivial and private matters such as family and personal issue.

As many have known, Megawati Soekarno Putri is the second daughter of 
the first president of Indonesia, Soekarno. Titled as the Father of Proclamation, Soekarno is widely recognized for his excellent service in the struggle for Indonesian independence. Megawati is one of Soekarno's daughters who constantly attracts media's attention, especially when she decided to pursue a political career in the 1990s.

The research finds that there are several articles published in Indonesian mainstream media which continuously related Megawati to her family issues. One of the articles discussing about Megawati and her family was Sukma: Rachma akan Dukung Mega (trans. Sukma: Rachma will Support Mega) published on Detik. Here, the writer used the unification of Soekarno's daughters as the news frame to talk about Megawati's family. Putra-putri Bung Karno Berkumpul (trans. Soekarno’s Daughters Gathered) published in Tempo also put internal conflict within the Soekarnos family as the main frame. Furthermore, media reference to family was also found in Liputan6's Megawati, dari Ibu Rumah Tangga Menjadi Presiden (trans. Megawati, from a Housewife to be a President). On their coverage, media often implied that 'Megawati was just a housewife happen to be Soekarno's daughter', a sense that media took lightly of her political ability. Observing such patterns, we can see how media would prefer to talk about female politician's relationship with their powerful family member, rather than talking about their own political ideas.

Meanwhile, American media also made coverages about Hillary Clinton in relation to her family and personal matters. If Megawati was highly associated with her father Soekarno, then Hillary was vastly linked with her husband who was also the $42^{\text {nd }}$ president of America, Bill Clinton. As Bill Clinton was publicly known as controversial figure with his extramarital scandal with Monica Lewinsky in 1993, media often talked about this subject in their coverage of Hillary Clinton. Some examples can be found in Washington Post's Clinton Talks about Dark Times, the New York Times’ Clinton Proudly Talks of Scars While Keeping Her Guard Up, and USA Today's Clinton's faith helped her cope with husband's infidelity. Here, we can see that the writers used family framing by placing woman in private sphere. This suggested that female politician can never be separated from family issue, especially when they have bad record about it.

Besides the scandal, media also frequently brought up topic about Hillary's 
reliance on Bill Clinton. Examples can be seen from The Wall Street Journal's Two Presidents in the White House? and the Los Angeles Times’ Hillary Clinton cold, calculating? Not according to Bill.

\section{Women and Gender Issues}

It is no secret that women and gender issues often become the main vision and mission raised by female politicians when they run for political position. Employing this strategy, on one hand a female politician will have bigger chance to gain votes from the constituents, especially those who concerns on women issue. On the other hand, it may actually be detrimental because, once again, it implies that woman is destined only to take care of domestic issues, with only wider area here. This notion is strengthened by media's constant coverage of women figure's involvement in womanly issue and topics, such as education, childcare, healthcare, food, and other social affairs. It seems that it is easier to find media's coverage of women's participation in womanly and 'soft' activities rather than their contribution in manly and 'rough' issues such as state security, war, or gun policy.

This issue can be seen from the USA Today's Clinton unveils details of her health care plan and the Washington Post's Clinton Presents Plan for Universal Coverage. As the title suggests, both articles talk about Hillary's presentation of her health care plan details for presidential campaign. With strong reference to her failed health care plan during Bill's presidency, media seems to provoke people to underestimate Hillary's ability in dealing this issue. Besides health issue, gender issue is often brought up by media, especially on how Hillary tried playing with gender card as her campaign strategy. Examples can be seen from The New York Times' Gift of Gall, the Los Angeles Times' Hillary plays the winning gender card, and Wall Street Journal's Did Sexism Derail Hillary Clinton?

On the other hand, media in Indonesia also associate Megawati with women and gender issue, which can be found in Liputan6's Megawati Meminta Perempuan Mendukung Capres Wanita (trans. Megawati Asked Women to Support Woman Candidate) and Detik's Menneg PP: Semoga Ibu Mega Terpilih dalam Pemilu 2004-2009 (trans. Minister of Women's Empowerment: I Hope Mrs. Mega Will be Chosen in 2004-2009 Election). In both articles, the writers emphasize how Megawati takes advantage of her status as a woman to gain sympathy 
from other fellow women. However, in an article published in Tempo entitled Megawati Diminta Peduli Terhadap Nasib Perempuan dan Anak-anak (trans. Megawati Asked to Care for Women and Children's Issues), Megawati is criticized by a women forum for her ignorant behavior towards women and children issues. Here, Megawati is seen only as symbol rather than a real woman leader.

\section{Fashion and Physical Appearance}

Aside from her natural instinct, being pretty seems to have become a social demand for every women, especially those who work in public spaces such as politicians. No wonder, then, fashion and physical appearance often become the main topics raised when media reported on women politicians. If this kind of coverage only happens once or twice for a while, then it could be counted for intermezzo or entertainment purposes only. Unfortunately, media often distort their focus more on female politician's physical appearance rather than their brains and inner qualities. Be it a praise or criticism, media's excessive devotion on female's appearance indicate that in media coverage, women continue playing the supporting role in politics rather than the main role.
One of the most controversial articles that invoke wide debates is published in The Washington Post entitled Hillary Clinton's Tentative Dip into New Territory Neckline and the Los Angeles Times’ Cleaving over Hillary's cleavage. By framing women politician using their physical appearance, it feels like Hillary's bodily appearance, compared to what she presented on the event, was a greater issue that public should focus on. This kind of notion would be misleading, because readers are invited to focus on physical appearance rather than the content of Hillary's speech at that night.

Women's passion for fashion issue also becomes the main theme in several media platform such as in The New York Times' Hillary Clinton as the Fashion Police: My Polka-Dot Dress Should Be Arrested, Wall Street Journal's Women in Power: Finding Balance In the Wardrobe, and USA Today's Out-of-style thinking. These articles talk about problematic relationship between woman politician and fashion in public discussion. While not all of these articles use negative tone, nevertheless this implies that women are still trivialized in politics by media's constant identification on things that have nothing to do with political issues they represent. 
Although Indonesian media do not show much attention to Megawati's appearance, at some point they tend to highlight female politician's association with something feminine such as fashion show. An example can be found in Tempo's article Megawati Buka Acara Kuntum Kahyangan di Istana Bogor (trans. Megawati Opened Kuntum Kahyangan Event in Bogor Presidential Palace). The event was a batik exhibition and fashion show attended by important figures in Indonesian government. Here, we can see that media makes Megawati's visit to a fashion show as a big deal that needs to be emphasized. On the other hand, in Detik's Perempuan ProReformasi Kecam Ajakan Pilih Paling Cantik (trans. Pro-Reformation Women Cavil the Invitation to Vote for The Prettiest One), Megawati is criticized for being sexist because of her remarks during a campaign. Using Megawati's remark as frame, the writer suggests the readers to perceive Megawati as a sexist figure who sees woman only from their physical appearance rather than actual brains.

\section{Political Relation}

Political relations often arise from kinship, such as parents to the children, grandfather to the grandson, a husband to his wife, or vice versa. If a family possesses a strong political background, it becomes a kind of tradition that the family's next generation will follow their predecessors' steps into politics. Considering the phenomenon of such political relations happening a lot around the world, media often link women politicians with their family members who have powerful positions in the government.

Political relation becomes an important issue as many American media cover the issue in their articles, such as the Washington Post's Hillary Clinton Embraces Her Husband's Legacy, the Wall Street Journal's In Evoking Good of '90s, Clinton Risks Memories of the Bad, and the New York Times' The Clintons Campaign in New Hampshire. Although public knows that Hillary is an independent individual who has a political track record of her own, in fact, her relationship with the former president cannot be separated since people keep judging her marriage with Bill. At this point, we can see how media often bring up political relations issue between woman candidates with the previous rulers. Be it positive or negative, it seems that women in media have not been able to stand as an independent individual. 
Thus, media used other variable to assess their quality as a leader; that is to see their relationship with other male politicians. Moreover, the Los Angeles Times' Hillary and Bill Clinton in Defeat and victory: When pictures tell the story and USA Today's Question for Hillary: What will Bill's impact be? also talk about Bill's powerful influence to Hillary’s way to presidency.

In Indonesian media, Megawati's figure is also closely linked to her predecessor, Soekarno. This trait can be found explicitly in Tempo's article Guruh Minta Rakyat Beri Mega Waktu Lima Tahun Lagi (trans. Guruh Ask the People to Give Mega More Five Years), Detik's Ratusan Orang Hadiri Haul Bung Karno di Perintis Kemerdekaan (trans. Hundreds People Attend Soekarno's Death Anniversary in Perintis Kemerdekaan), as well as Liputan6's Megawati: Saya Sudah Bekerja Maksimal (trans. Megawati: I Have Worked Maximum). In almost every chance, whether it comes from her own campaign spokesperson, her political rivals, or people's opinion, the reference of Megawati as Soekarno's daughter is always brought up by media.

\section{Stereotypes and Negative Traits}

Stereotype and media can never be separated. Media uses stereotype as a way to perpetuate social perception in favor of particular class or group. While several stereotypes are positive, negative stereotypes are at risk of becoming a kind of blind generalization, which makes it become the common reason of one group to isolate or even bully other groups. Mass media such as newspapers also employ stereotypes as their main frame in creating news coverage of women politicians.

Media often use strong tone of gender stereotypes in their coverage of woman politician. For example, the Los Angeles Times Clinton the organized which denounces woman's organized character or USA Today's Has the political risk of emotion, tears faded? which talks about woman's emotional state. Besides stereotypes, media are also fond of writing coverage about the disadvantage of being women. An example is The New York Times' Women Are Never Front-Runners. Not only that, media also talk negative traits of woman as seen in the Washington Post's We Scream, We Swoon. How Dumb Can We Get? and The Wall Street Journal's article Sex and the Presidency. It seemed that media always finds a way to criticize female 
politicians and put them in awry position. If they show dominant feminine side such as Congressman Nancy Pelosi, they are condemned as not strong enough to lead the country. However, if they do the opposite and show their strong and tough side, women will be judged by media as ambitious person who makes them deficient as a woman.

In Indonesian media, stereotypes might not be the main theme raised by media in their coverage of woman politician. Rather than that, media often relates woman leader and religion, especially Islamic view. Examples can be found inLiputan6's Kiai NU Jatim Menolak Presiden Wanita (trans. NU Priests in East Java Refuse Woman President) and Tempo's Tim Sukses MegaHasyim Minta Dukungan Ulama Banten (trans. Mega-Hasyim's Campaign Team to Ask Support from Bantenese Islamic Leaders). In both articles, media blows up the news about Islamic religious leaders' agreement to forbid woman candidacy as president. Despite the seemingly neutral tone, by using particular frame that corner woman leaders' position, the writer suggests that woman should not be chosen as leader since it is not in line with religious belief. Not only religion, personal character also becomes media's focus. For example, Detik's article Berlomba Mencari Simpati Massa (trans. Race for People's Sympathy) also talks about how Megawati has made use her privilege as president to gain political benefits for herself.

Framing as the result of media and journalists' filter contributes to the creation of public's opinion toward certain news. In fact, at one point, media coverage toward particular candidates can profoundly affect election outcomes. Specifically, gender bias in media coverage can disadvantage female candidates than male candidates in the same race (Uscinski and Goren, 2001: 855). In the case of Hillary Clinton's presidential bid on 2008, she was defeated by her rival, Barack Obama at the end. It also happened to Megawati Soekarno Putri who was stopped in the second round of 2004 presidential election after being defeated by Susilo Bambang Yudhoyono.

Particularly in Hillary's case, many people especially feminists argued that sexist media coverage had driven her out of the race. Meanwhile, in Indonesia, there was no party claiming the existence of sexist media coverage toward Megawati. Although there is a uniform tendency for media to cover particular issues, each media gives different emphasis and portion 
in allocating their slot to present this news. In theory of Critical Discourse Analysis, van Dijk explains that social cognition is vital in analyzing a news item in order to get a better understanding of the social context. Through social cognition, we can assess how media and journalists behind news production work and think. Thus, we can figure out how the news is produced and what factors make the news framing significant.

\section{Social Perception of Woman as Leader}

Stereotype is one among many things that will limit someone's perception toward something. Due to stereotype, one's perception will be mechanically formed by the knowledge he acquires socially rather than by his own experience. As consequence, his interpretation toward this matter will be very partial. In the previous sub-chapter analysis, we find that media often make use stereotype in their framings toward women politician. Because of stereotype, one ordinary issue can be perceived and even turned into something extra-ordinary and sensational when it is committed by a female politician. For example is crying, a common emotional activity which causes mixed public response when media spotted a woman politician sheds tears in an event.
Social perception on woman's relationship with her family also influences media coverage on women politician. Incidentally, two figures discussed in this research are known with their intimate relationship with previous power-holders in Indonesia and America, so media provides coverage on this issue too.

\section{Media Ideology}

Behind the creation of framing, there is definitely media ideology interest. As repeatedly stated, media plays a great role in shaping people's opinion towards particular topics. Media as the channel of information do not necessarily tell the public an information as it is, but rather filter and develop the information first through a framing process. Although objectivity should be the main goal for every media, we should note that there is no media which is a hundred percent neutral in their editorial, since there remain some gaps of subjectivity influenced by certain ideology. In the United States, copious studies have been conducted to examine media's affiliation with particular political faction as well as their coverage affinity, whether it inclines more to the right wing (conservative) or left wing (liberal). Thus, people could know better where the editorial tends to side. 
Meanwhile, in Indonesia, there are not much studies conducted to examine media's affiliation and inclination toward particular political groups. Different from America public which sees the importance of clear statement on media's political stance, there is yet a study on the level of liberalism or conservatism of Indonesian online news media. From three online news media used in this research; Tempo, Detik, and Liputan6, there is no study yet mentioning their affiliation on political groups. Nevertheless, Goenawan Mohamad, Tempo's senior journalist stated that media does not have to be neutral, but media should not spread rumors as well as tell lies against certain parties (Tempo, “Goenawan Mohamad: Media Tak Harus Netral”).

\section{Political Dynasty}

One striking similarity between Hillary Clinton and Megawati Soekarno Putri is that both have family member that once ruled the country. Furthermore, the men behind these women politician are recognized for their excellent leadership track record that they have strong supporter basis even after they step down from presidency. Given the central role of Bill Clinton for America and Soekarno for Indonesia, many media associate these figures with women politician when Hillary and Megawati's presidential candidacy coming to the surface. Either directly or indirectly, media argue that women's popularity or involvement in politics has something to do with their husband's and father's big names. It implies that if only Hillary were not Bill's wife or Megawati were not Soekarno's daughter, they would not be able to reach the position they achieved today. Here, media underestimate the ability of women's leadership by constantly reflect on the fact that they have direct and close relationship with the former leaders.

Considering the pervasive social conception that woman will not make a great leader, in order to boost their electability, women need dominant figure as their backup support, which is male. This male figure plays a vital role in endorsing woman's character in politics since he is believed to be able to provide good example and mentoring for woman who wants to fight the other male candidates in the race. Stemming from this notion, many media employ political dynasty as their framing in presenting women politician coverage. As political dynasty has more negative connotation than the positive ones, media coverage on women politician within this theme often 
leads to misleading conception that might backfire her image.

\section{Conclusion}

In Indonesia, the country's growing reputation as the biggest Moslem population in the world is predicted to influence the way media perceive woman leader. However, the research shows that it actually does not affect much towards political business. It is found that media do not pay much attention to the religious view of woman leader. There is neither direct objection from media while presenting news coverage about Megawati nor direct reference to certain religious interpretations. Instead of religious values, it seems that Indonesian media pay more attention to the candidate's political relation and social perception. Not only Megawati’s family was highly scrutinized during her presidential campaign, media also keeps associating her with Soekarno. Media also repeatedly bring up stereotypical issue of woman politician such as focusing more on her physical appearance rather than her work plans. This way, media trivializes woman's candidacy by leading public's focus on minor things that have nothing to do with her political view.
On the other hand, American media still clings onto the stereotype of woman leader that it influences their way of presenting news coverage toward Hillary Clinton. The commonest traits used by media to talk about Hillary's candidacy are physical appearance and association of family. It is quite easy to find articles written in sexist and negative tones in describing Hillary's physical appearance and behavior. Finally, woman will never be separated from domestic issue as media find that talking about her marriage life is much more interesting than discussing her future work plans.

Towards the end, from the analysis of news coverage on Hillary Clinton and Megawati Soekarno Putri, we find striking difference between media in two countries. It seems that American press and media is way more open and at liberty in expressing their opinions toward particular candidates. As can be seen in the previous chapter, there are many articles with direct satirical remarks and sexist criticisms toward Hillary.

While in Indonesia, it is difficult to find the same thing. It seems that media are more reluctant in expressing their opinions toward Megawati. So if we look at it, media coverage on Megawati is done in much very subtler and implicit way, let 
alone using satirical writing style. Meanwhile, media in America is more to the point and explicit in proposing their opinions about Hillary's candidacy. Finally, learning from the media framing toward woman politician, we can conclude that despite feminist achievement in many areas, woman are still highly perceived as unfit to be in political world.

\section{References}

Caroll, Susan J. 2009. Reflections on Gender and Hillary Clinton's Presidential Campaign: The Good, the Bad, and the Misogynic. Politics \& Gender, 5. USA

Eriyanto.2001. Analisis Wacana, Pengantar Analisis Teks Media. Yogyakarta: LKiS

Gouda, Francis and Zaalberg, Thijs Brocades. 2003. American Visions of the Netherlands East Indies/Indonesia: US Foreign Policy and Indonesian Nationalism 19201949). Amsterdam University Press

Holtz-Bacha, Christina. 2013. Who takes care of the children? The presentation of female top politicians in the media. Revista Compolítica, $n$. 3, vol. 2, ed. jul-dez, ano 2013

Kellner, Douglas. 2002. Presidential Politics: The Movie. AMERICAN BEHAVIORAL SCIENTIST, Vol. 46 No. 4, December 2002 467-486

Lois, Tyson. 2006. Critical Theory Today Second Edition. New York: Routledge
McDowell, Tremaine. 1948. American Studies. Minneapolis: The University of Minnesota Press

Singh, Amrit, Skidmore, Max J, and Sequiera, Isaac (eds). 1995. American Studies Today: An Introduction to Methods and Perspectives. New Delhi: Creative Books

Sobur, Alex. 2001. Analisis Teks Media. Bandung: PT Remaja Rosda Karya

Sykes, Richard E. 1963. American Studies and the Concept of Culture. American Quarterly, Vol. 15, No. 2, Part 2: Supplement (Summer, 1963), pp. 253-270. The John Hopkins University Press

Uscinski, Joseph E and Goren, Lilly J. 2011. What's in a Name? Coverage of Senator Hillary Clinton during the 2008 Democratic Primary. Political Research Quarterly 64(4) 884-896

Van Dijk, Teun A. 2001. "18 Critical discourse analysis”. The handbook of discourse analysis, pp.349-371.

Zanden, James W. Vander. 1988. The Social Experience: An Introduction to Sociology. USA: Random House Inc

\section{Electronic Sources}

Bedard, Paul. Media Sexism Doomed Hillary's 2008 Bid. 2011. Retrieved from

http://www.usnews.com/news/blogs/ washingtonwhispers/2011/12/23/media-sexismdoomed-hillarys-2008-bid at January 6, 2015

Harper, Jennifer. Gender bias did in Clinton? 2008. Retrieved from http://www.washingtontimes.com/ne 
ws/2008/jun/06/gender-bias-did-in-

clinton/ at January 6, 2015

Liputan6. MUI Yogyakarta

Mengeluarkan Fatwa Haram soal

Capres. 2004. Retrieved from

http://news.liputan6.com/read/81155

/mui-yogyakarta-mengeluarkan-

fatwa-haram-soal-capres at 16

February 2016

Steinem, Gloria. 2008. Women Are Never

Front-Runners retrieved from

http://www.nytimes.com/2008/01/08

lopinion/08steinem.html at April 27, 2016 